\title{
Nostalgia
}

In

\section{Andrew Motion's Essex Clay: An Analytical Study}

\author{
By \\ Dr. Reham Mohammed Abu Zaid \\ Lecturer of English Literature \\ Al-Azhar University \\ Azhar Faculty for Girls \\ $10^{\text {th }}$ of Ramadan Branch \\ rabuzaid@azhar.edu.eg
}




\section{Abstract}

The British former poet laureate, Andrew Motion (1952 - ), now lives in America, feels nostalgic for his homeland, his childhood memories, and his late parents, especially his mother whom he loves so much. In his autobiographical verse volume, Essex Clay (2018), Motion expresses this nostalgia. By doing this, the poet has tried to make his poems curative and to find a way out of these painful feelings of nostalgia which haunt him. This research paper tends to trace these feelings of nostalgia in the poems of this volume trying to discover their curability and the poems' therapeutic effect.

Key Words: Nostalgia - Autobiography - Therapeutic Writing (Writing Therapy) Poet Laureate - Homeland.

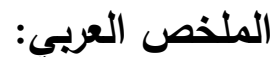

جُبلَتِ فطرةُ الإنسانِ على حبِ الأوطانِ والحنينُ للطفولةِ حيثُ لا قيمة للزمانِ ولا معنى للأحزانِ.

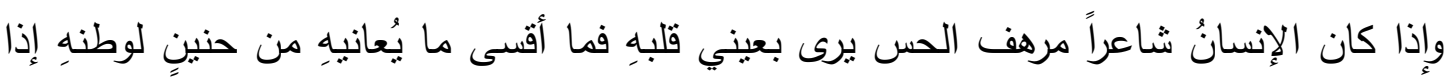
ما ارتحل بعيداً عنه. فهنا لا يملك إلا اجترار الماضي وتجرع الألم مع كل ذكرى تتازع خاطره. فيهرع إلى قلمِهِ ليكون الملاذ الوحيد له في غربته ليهدّأ من روعه. و لقد عانى أمير الثعراء البربطاني الأصل و المولد، أندرو موشن، من تلك المشاعر في غربته حيث يقطن و يعمل بالولايات المتحدة الأمريكية في الآونة الأخيرة. فجاءت كتابته لديوانه، "طمي إيسكس"، نوعا من كتابة السيرة الذاتية ولكن في شكل قصائد ومع ذللك فهي تحملُ في طيَاتِها حنينَه لكل شئ في موطنه "إيسكس" بإنجلترا: لطفولته، لوالديه المتوفيين، لكل ما في وطنه حتى طيه. فما أغلى طمي أو تراب الوطن على نفس المغترب عنه ويا له من تِبْرٍ نفيس.

وتهدف الورقة البحثية لسبر غور نفس الثاعر والغوص في ذكرياته من خلا تحليل قصائد ديوانه محل الدراسة والتمحيص. واقتفاء سيرته الذاتية المقدة في تلك القصائد. كما تسعى لإلقاء الضوء على الأثز النفسي الإيجابي لكتابة تللك القصائد، كنوع من العلاج لتخفيف وطأة الحنين للماضي وللوطن ولعلاج الألم النفسي الذي يعانيه الثاعر أو بالأحرى هذه القصائد أصبحت نوعاً من "الكتابة العلاجية" أو "العلاج بالكتابة". كلمات مفتاحية: الحنين - أمير الشعراء - سيرة ذاتية - الوطن - الشعر الحديث. 
To look back once more to the person's past especially after leaving his homeland, is to create a highly sensitive state of ruminating on old memories with painful nostalgia. In addition to its tormenting yearning and psychological pain, nostalgia is always linked by psychologists to some symptoms as: "insomnia, depression, and anxiety" (Matthews 1), as well as some physical symptoms. In her essay, "Are Feelings of Nostalgia Really Just a Symptom of Depression?" Sophie Matthews cites some of the symptoms which accompany depression caused by nostalgia, among them are "feelings of sadness, tearfulness, emptiness, or hopelessness" (1). So, for a long period of time, nostalgia was considered as a psychological disease. Besides, it was variously classified for a long time as an "immigrant psychosis," a form of "melancholia" and a "mentally repressive compulsive disorder" among other mental ailments till the beginnings of the 20th century (Tierney, "What is Nostalgia" 2).

However, by the end of the 20th century, negative symptoms of nostalgia began to be seen as having positive effects. Consequently, nostalgia was no longer considered as a cause of depression, but "a means to counteract it" and the other accompanying symptoms (Staughton 2). Psychologists have depended on the "defensive mechanisms" of human beings' brains, regarding nostalgia as one of these "defensive mechanisms" not one of the psychoses. They explain that "our minds are often self-protective" against whatever harms them such as depression, melancholia, and insomnia". Additionally, nostalgia is "essentially a means of romanticizing the past through the filter of our minds" (Staughton 2). Hence, memories can enhance our moods and give our lives a meaning; we feel that one day we had good moments, family members and lovers. In spite of "the negative aspects" of being nostalgic like remembering dead people, one can find out "the positive things" out of these negatives (Tierney, "Science" 00:03:40). In the above quoted interview entitled "Science of Nostalgia", aired on The New York Times: Timesvideo, John Tierney explains the positive sides of nostalgia stating that:

For most people, it [nostalgia] can rock loneliness, it can rock anxiety, I mean after I look back wistfully to the past I can see something more optimistic about the future, and it gives your life content nodding your life. It reminds you that there are people in your life who are important to you. You got a social support. It gives your life more meaning ... I have old experiences that I can put them together, it gives me the sense that my life has this flow that I have these memories and I have these friends.

$(00: 02: 11-00: 02: 54)$ 
Thus, the person may end up with a sense of belonging and association. Also, when he shares his memories with someone else, he feels close to them. This gives him happiness and some sort of psychological relief as: "reliving past memories may provide comfort and contribute to mental health" ("Nostalgia"). Furthermore, recalling old memories may give meaning, hope, stability and continuity to the life of the nostalgic person, as he believes of having sound roots. So, although nostalgia could be painful and a source of negative feelings, it can have positive effects. Briefly, it can be summed up as "a bittersweet emotion" as Tierney says in his article "What is Nostalgia" (1).

To get rid of the negative symptoms and effects of Nostalgia, and to attain its gains, one should find a healing means. This healing means could take the form of writing. When someone becomes trapped in his/her memories, he/she spells them down on paper in order to re-express his/her feelings, document these memories or record their reflections and reactions to them. Writing in this way releases the stress and the torment of these memories. In this case, writing is considered as a therapy, or as called by psychologists "writing therapy" / "therapeutic writing" (Bolton "Inroduction" 2).

Writing is "a powerful therapeutic technique" (Esterling 94). It is a deeply contemplative and reflective process of reproducing past experiences and their related emotions and memories creatively in appropriate language. Thus, writing about traumatic experiences will "re-stimulate the original difficult feelings at first. It is important that participants are informed about this and reassured that this 'selfconfrontation' is part of the process" of healing (Wright 3). Consequently, literary men have always endeavored to find "the link between emotion, disclosure and health" (Wright 2). For instance, Virginia Woolf $(1882$ - 1941), in her autobiographical book, Moments of Being (1985), said that she no longer feels obsessed with her late mother after writing her novel "To the Lighthouse" (1927). She writes: "I did for myself what psychoanalysts do for their patients. I expressed some very long felt and deeply felt emotion. And in expressing it, I explained it and then laid it to rest" (81). Hence, creative therapeutic writing is self-remedial. It brings the writer face to face with his problems, obsessions and nostalgic feelings. Yet, every literary genre of writing has a special therapeutic power.

As one of the most important literary genres, Poetry, "the Queen of Arts" (Wilson 357), has an intense therapeutic effect. Notably, poetry weaves the psychological, the emotional, the spiritual, the rational and the physical sides 
together in a concise literary form; the poem. Through the innovative lexical and figurative use of language, a poet finds a way towards self-awareness and new insights and hopes. It probes into the subconscious searching for feelings and memories promoting self-reflection and truthful expression, some of these feelings and memories are painful. Poetry, then, plays its role as a strong healing factor. Its effect can be felt not only on the poet himself, but also on his readers and listeners. Therefore, each reader or listener feels that his/her painful experience and tormenting nostalgia are curable: "the use of and familiarity with the power of imagery and metaphor has always linked poets and artists to healers" (Flint vi). Thus, the therapeutic poetry writing experience is "a process - rather than a product" (Bolton, The Therapeutic 107). It is a process of self-exploration, self-confrontation and self-analysis, then self-help and healing. In this case, poetry becomes a medicine-like remedy; "poetry and medicine have gone hand in hand since Apollo was the god of both" (Bolton, "Every Poem" 119). Stating the powerful effect of poetry, the British poet, Andrew Motion writes: "Poems are a hotline to our hearts, and we forget this emotional power at our peril" ("Hotlines" 6).

This research paper purports to shed light on the therapeutic effect of writing poetry through tackling Andrew Motion's volume, Essex Clay, as an example. Written from the perspective of this distanced poet Essex Clay dealt with many nostalgic feelings. In doing so, the poems could alleviate the tormenting feelings and the other symptoms which accompany nostalgia through a constant process of self-confrontation, confession of the reality, self-help, accepting and overcoming the loss, and at last finding a way out or a hope to go on with life. Motion could manage to turn the negative effects of nostalgia into positive ones or at least to be lessened and mitigated. Hence, these poems have played a curative role for the poet. They have become like 'a therapy' for his nostalgia.

Nostalgia is a common feeling among mankind. Each one in any place or in any time can undergo it. During its long history, psychologists have defined nostalgia as a psychological disease which has hurting symptoms such as insomnia, depression, anxiety and other physical symptoms. In the twentieth century, modern psychological researches have proved by experiments that the negative effects of nostalgia and its harmful symptoms can be turned into positive ones through a healing process. This healing process can become true through using many means; one of them is literary creative writing, especially poetry.

Poetry as an intense and condensed emotional composition can have a curative power. Poetry vividly expresses the inner feelings of its writer. It can record 
sensitively the poet's nostalgic feelings intensely. Through writing them, the poet can pass through the steps of the process of healing from the negative effects of nostalgia. He can find a way out of them to achieve psychological relief, can realize a new hope, and can discover positive sides in life. Therapeutic poetry can also be of a great benefit to readers. They will discover that poems can alleviate their tormenting feelings and mitigate their feelings of nostalgia.

This research paper purports to achieve some aims such as: tracing the nostalgic feelings and their negative effects and symptoms in Andrew Motion's volume of poetry, Essex Clay. Second, it attempts to trace the steps of the therapeutic power of the poems of this volume and how they have mitigated the poet's tormenting feelings. In doing so, it refers to the therapeutic power of writing poetry in general.

The British former Poet Laureate, Andrew Motion (1952 - ), who now lives in America, has recreated his memories in his autobiographical prose book, In The Blood: A Memoir of My Childhood (2006), in Britain. After twelve years, with a more nostalgic tinge, Motion reproduced his past, but this time in verse, in his volume, Essex Clay (2018). The characteristic, which differentiates these revived memories of this verse volume, is that they have been written from a perspective of a distanced nostalgic person.

Being away from his homeland, in a foreign country, Motion remembers his deceased parents, his village, and his childhood memories and friends. Consequently, his irrecoverable nostalgic feelings torment him tremendously. He tried to find a healing way out of these tormenting nostalgic feelings through writing his verse volume, Essex Clay. Hence, he says: "I wanted writing to feel normal" (Motion, In The Blood 286).

This research paper purports: first to trace Motion's feelings of nostalgia, its symptoms and impact on the poems of his volume, Essex Clay, inspecting his memories tackled in these poems. Second, the research paper tries to shed light on the curative value of writing poetry in general and writing this volume in particular, by showing how writing these poems has had soothing and healing effects on the poet's painful feelings of nostalgia. In other words, the paper deals with the collection as a 'therapeutic writing' or 'writing therapy'. Thirdly, the research paper endeavors to reveal whether writing these poems could relieve the poet's suffering, depression, alienation and grief accompanying losing the beloved ones and living far away from homeland. The paper also investigates whether he could change these feelings of nostalgia into positive factors in his life. 
Andrew Motion's love for his homeland especially his village, Stisted, was phenomenal. He was born in London on 26 October 1952. His family lived in Hatfield Heath in Hertfordshire, and then they moved to Stisted, near Braintree in Essex, when he was about 12 years old. There, his memories began to shape and also his first poetic sense started to bloom. He wrote: "Stisted is where my eyes first opened. That's where I first began to care about poems. And that's where the things I was reading fused with the things I was seeing" ("Andrew Motion on Stisted" 1). Although Motion now lives in Baltimore, U.S.A., where he works as a Professor of Arts at Johns Hopkins University, yet, he is still attached to Stisted, Essex. He travels to it from time to time to visit his children, friends, his younger brother, Christopher (Kit) and his parents' graves. Motion wrote on his Twitter page on 3 July 2019: "About to fly back from Baltimore to London, for a week of seeing my children and friends. And reading at Ledbury in Saturday. Right now, though, big thunderstorm over Chesapeake." He publishes pictures of Stisted / Essex from time to time on his Twitter page. He is still longing for it so much.

Concerning longing for a specific place, Susan Matt, the author of the book, Homesickness: An American History, writes about nostalgia for a specific place: "A lot of times, people thought they were longing for a lost place, but then they go to that lost place and realize they were longing for a lost time" (130-131). Moreover, Matt also differentiates between 'homesickness' and 'nostalgia'. In this respect, a "homesick" person is "separated from home by a gulf of geography"; whereas a "nostalgic by a greater gulf - the gulf of time" (130). Therefore, Motion is always homesick and nostalgic for Essex in particular and for England in general. They are rooted in his past and memories.

In Essex, Motion had a special place for writing, since he was a teenager where his writing consciousness began to be formed. He wrote: "The Ashground was my place - where I could read and write and doze and be invisible" (Blood 305). Now, he has the sharp faculty of conjuring up every detail of the place, in his prose and poetry. He describes perfectly the kinds and the colors of the trees, the plants and the birds. Also, the Ashground was and is still his shelter when he is sad. In 2006, when he knew that his father was seriously ill and was going to die soon, he went there, to the Ashground: "Until he arrives at good cover / the horizon-wood / the Ashground" (Essex 69).

Early in his life, Motion had to stay far away from the Ashground and the village and Essex in general to attend his boarding schools (Maidwell and Radley). This experience implanted to him an early feeling of homesickness and an early 
awareness of alienation and nostalgia, which had been deeply engraved in him, and grew more and more with time and circumstances. He explains how homesickness affected him even physically saying:

Homesickness was far worse than going to Australia. It meant having a lead weight wrapped round my whole body, like in a coffin. My head went dark, and my stomach squashed down flat. In the end it got so bad, I asked God to make time get a move on - which made me wonder whether I was going mad, and would soon start sprouting hair on the palms of my hands. (Blood 168)

The above astonishing description of the feelings of homesickness summarizes Motion's early suffering from homesickness. It also refers to the possibility of the escalation and worsening of these feelings when he becomes distanced and nostalgic later on, as is happening now. His stay in America has aggravated these tormenting feelings. Therefore, he yearns now for every detail in his homeland, even its clay. Accordingly, throughout his last volume of poetry, Essex Clay, written in America, Motion describes the natural scenery of his village, especially its clay. Consequently, this 'clay' has a constant presentation and a symbolic value in this volume. No wonder, then, that the volume is entitled Essex Clay. Additionally, he is attached to this clay as it contains the corpses of his parents. The first time Motion mentions the word "clay", in the volume, is in the first part, as he writes that: "and below this the clay six feet deep / malevolent pasty face / ash smears and ochre / a dead weight but in fact alive". He describes here how Essex clay contains his mother where she has been buried. Although she has died long time ago (since 1978), he is still obsessed with her. She is still "alive" for him in his imagination. The second time the poet mentions his village's 'clay' is when he remembers his mother after knowing of her fatal accident:

a life

vanishing along with the moment he sees it

as the pasty clay hand stretches

from underground and garbs.

(Essex 28)

The repetition here, in the above lines, of the word "clay" indicates that his nostalgia for Essex clay is not only because it is his homeland (or his motherland, as it is related to his mother's "pasty clay hand"), but also because it contains the 
corpse of his beloved mother. This clay nourished his mother's body when she was alive, and contained it after her death. Additionally, the first part of the volume also ends up with "smears of Essex clay yellowing the heels" of his father's "highly polished shoes", while he was standing in the graveyard during "his mother's funeral" (63). The poet moves smoothly from the expression of his nostalgic feelings for 'the clay' of his country and its relation to his mother, to its relation to his father also. This reflects the intensity of his nostalgia for his country's clay.

In the second part of the volume, where Motion describes the last days of his father's life in the hospital ward, the air "raises him off the clinging ground / the clay that detains him" (80). Again, the poet refers to the same idea that his country's clay constituted his father's body, as it did his mother. Then, Essex clay contained his father's body, after twenty eight years of his mother's death, he wrote:

The sexton's spade in the churchyard

which has removed the surface grass

in delicately snarling curls

and opened the Essex clay

to a depth of six feet

exposing black root-wires scrabbling for a hold

(Essex 85)

The Essex clay has been dug "to a depth of six feet" to have the body of Motion's father as happened before for his mother. The poet mentions this depth to symbolize his considerable attachment to and nostalgia for Essex clay which contains his late parents deeply inside it. Accordingly, the phrase "the root-wires" symbolizes Motion himself; his roots are there in this clay. They are sound roots; even if the hardships of life turn them away; "The sexton's spade", they are "scrabbling for a hold". The color "black" in the last line of the above quoted lines is ominous. It symbolizes the poet's depression and suffering. In this sequence, "the bitter-sweet" effect of nostalgia can be felt. The poet's sadness and torment can be made out in the connotations of some words as: "spade, curls, opened, depth, six feet, black and root-wires". In contrast, the positive effect of his nostalgia appears, for example, in the intended meanings and connotations of some words as: "churchyard, removed, delicately, snarling, exposing, and scrabbling for 
a hold". The therapeutic power of writing poetry is expressed in the word "exposing", because it conveys the poet's self-exposition and self-confrontation. He has passed through the process of healing, through removing "the surface grass" which constitutes "snarling curls", going deeply inside Essex clay to confront the causes of his nostalgia and its "black" symptoms, and at last he finds out hope "scrabbling for a hold". A new hopeful insight out of his tormenting nostalgia for his late parents and for Essex clay can be felt in the lines, due to the curative power of his poetry.

Therefore, the curative power of Motion's poetry helps him to overcome his nostalgic feelings for his old friends in Essex and his memories with them. Again the theme of his attachment to Essex clay appears in his tackling of his teenage friendship with his only girl friend, Julia or as he calls her 'Juliet' in the volume. In the first part, she appears, as he goes to visit her, when the fatal accident of his mother happens. Also, in the third and last part of the volume, she appears as the main character in the part. The whole part is devoted to her and her meeting with Motion after forty years from their last encounter. Motion knows then that she works as a producer of documentary films, has married and has two daughters. Yet, she had a horrible accident that left bad effects on her memory and indelible scars on her face. In the following lines, he sorrowfully describes the natural scenery of Essex while she was telling him about the accident:

Midwinter fields

no footprint

among flint bones

and bristly Essex clay lumps

no shadow

the seething snow surface

opening

and closing its lacy arms.

(Essex 98)

Julia tells him that she stayed "unconscious for three days", because of the accident. Hence, the above description is full of sadness, depression, and suffering. It was "Midwinter", with its severe coldness symbolizing death and stiffness. The 
phrases "no footprint" and "no shadow" refer to isolation and solitude. The horrible phrase "flint bones" stands for death, harshness and hardness. The wind was so strong that it left "the flint" bare. The adverb "bristly" adds to the implications of harshness. The paradox in "the seething snow surface" expresses the illogicality of the accident and his refusal to accept it. Deeply inside him, his feelings are also "seething" not only the "snow surface". There is an antithesis and a paradox in "opening" and "closing" to clarify the irritable circular movement of the "snow surface". "Essex clay" here is related to Juliet. She is part of it, just like his parents. In the period of her unconsciousness, she lay like a 'lump' of clay and didn't realize anyone or recognize anything. Again, the idea of relating Essex clay to his love ones aggravates his nostalgia for it and intensifies its tormenting effects.

In spite of all these negative tormenting effects of the poet's nostalgia for his homeland, he can find a way out of them during his self-exposition and exploration process in writing poetry. Here, the poet discovers that the damaging aspects of the Juliet's accident can be considered weak or "lacy". They can be overcome. There can be a positive side of all these negative feelings. The metaphor: "opening and closing" and the personification: "its lacy arms" hint at these positive sides. In the metaphor: the tenor is the snow surface, the vehicle is a door, and the ground of comparison is discontinuity and inconstancy. Thus, the poet's nostalgia for Essex clay can be surpassed by his therapeutic poetry.

The healing power of the therapeutic poetry against the negative effects of nostalgia can be found repeatedly throughout Motion's long poem Essex Clay. Its first part tackles Motion's nostalgia for his mother. He deals with his close attachment to her, her riding accident and her slow death. Remarkably, he loves his mother so much: "mum and I [were] glued together" (Blood 295). Notably, it is not the first time that Motion writes poetry in order to mitigate his painful suffering caused by the loss of his mother. Early in his literary life, in his first published volume, The Pleasure Steamers (1978), when he was teaching at Hull University (1976-81), Motion wrote a series of poems entitled, "Anniversaries". These poems tackle his visits to his mother in her hospital ward in four successive anniversaries of her fatal horse riding accident (Pearsall 111). His mother had this accident when Motion was about 17 years old. She underwent a neurosurgery operation and remained in and out of coma for nine years till her death in 1978. She has always remained a recurrent motif in his poetry haunting him and intersecting any other one. For example, in his long narrative poem "Independence" (1981), which is supposed to deal with the independence of India and the personal life of a British 
colonialist who lost his beloved wife, the image of Motion's mother recurs strongly in the narration:

A scar of yellow clods.

The scratchmark of something

vanished. A dry scuttle.

You will wake up,

I was thinking, wake up,

crouched with my head tilted

sideways as if I might

just make out your voice.

(Selected 36 -7)

Constantly, his mother has remained his Muse and the main motivation for his poetic inspiration, even when he tackles a different subject other than her. He states that: whatever he is writing about "by the end of the poem I'm writing about my mother again" (quoted in Pearsall 110). No wonder, the first word by which he begins his autobiographical book, In The Blood (2006), is "Mum". The first chapter is about the day before her accident and the accident itself in detail. Whereas the last chapter of the same book, chapter twenty two, is about the day after her accident and the following days, as well as the reaction of every one of the family to the accident and its effect on them all. At the same time, she exists in between; in every chapter or in fact on every page, her characteristics, her clothes, her words, her deeds, her opinions, her father's and mother's families, her daily routine, her perfume, her car, her dog and horse and everything about or related to her. In an elegiac way, he also ends the book with her words: “even though we weren't quite home yet, she could always say: 'here we are', and pause then almost repeat herself as if she didn't believe what she was seeing: 'Here we are at last' " (Blood 326).

Evidently, Motion is obsessed with his mother. The nostalgic memories of the first part of Essex Clay, related to his mother, are presented in a retrospective narrative form. Motion is known "as a narrative poet"; because "his verse" always "moves along a tract of storytelling that often notably blurs many of the distinctions between prose and poetry" (Sexton 1). Using this narrative technique helps him in his self-exposition, self-confrontation and healing process. 
Correspondingly, he narrates the events perfectly, ruminating on their painful impact. He begins the poem with lines which set the scene for his narration. He describes the frosty scene as follows:

The intact frost of early morning and a blade of ice

drawn from the tap in the stable yard.

The village as they drive through

half asleep under twisting chimneys.

The church Victorian Doomsday

moored to the hilltop edge

with its pretty flotilla of graves.

In these opening lines, the poet introduces the surrounding natural scenery in Essex on the day before his mother's accident in a reflective impressionistic way. He describes the place from the perspective of a nostalgic person who has suffered loss and bereavement. As a result, the natural elements stand for ominous symbols. The frosty scene portends a scene of aridity and negation. Additionally, the poetic diction acquires sinister connotations. Motion depicts the severe coldness as: "intact frost / a blade of ice". The church was "Victorian Doomsday" and was "moored to" the "edge" of the hilltop having "pretty flotilla of graves". The chestnuts were "bare" and "shattered with daylight". "Gravel" was "in the ford". The "brimming stream" was "Blackwater". The pebbles were "tawny". The river was of "shining tar shivering underneath". "Last night" was full of "snowdust". The fields were "ploughed". The wind was so fast. There were "clay clods", and "drift-triangles". The "flints" were like "hip bones and knee bones". Therefore, the poet prepares the reader to the impending catastrophe that he will write about.

In the above quoted opening stanza, Motion uses the third person plural pronoun "they" in the fourth line in order to speak about himself and his mother in a collective way that expresses their close relationship. This usage will be changed after the accident. Notably, the poet begins the narration by telling that his mother has driven her "Hillman car" to drop him in a bus station to go to Juliet's house, to attend a party and come back in the following day. The same day has been his 
mother's "hunting day" (Blood 1). The run-on-line technique helps the poet to complete his narration according to the flow of the memories in his mind. The motion of the lines is as fast as the car she has driven and the scenery has been changing. He is still describing perfectly the natural elements along the road with their hints of the impending catastrophe. The free verse and the way in which the poet divides the words in the lines and divides the lines themselves help the poet to focus on the inherent meaning and the ominous alarm of the diction.

In the above opening stanza, poetic license is frequently used, as for example in: "Last night's snowdust / in suddenly wide-open ploughed fields." (5), where there is no verb in this sentence. This is noted recurrently. Punctuation also may be disregarded. It is known that therapeutic writing generally and therapeutic poetry in particular may be "free from the constraints of spelling, style, grammar and chronology" (Wright 3).

Motion also uses symbols masterfully in the poem as when he uses the white colors, in this stanza, symbolizes the paleness of death and petrifaction. The black colors symbolize depression and mourning. The daylight symbolizes reality and destiny. The coldness of the weather symbolizes death. These symbols orchestrate together to draw the picture and foreshadow the events of narration. They also convey clearly the psychological state of the poet and his tormenting and depressive nostalgic feelings.

Also in order to reveal his tormenting nostalgic feelings, the poet, suddenly, separates the third plural pronoun "they" into "his mother" and "he", using the third person singular pronouns. This separation of pronouns coincides with their real separation, caused by the fatal accident. The use of the third - not the first pronouns refers to her absence, which distresses him so much and makes him feel alone in life. Motion shifts to describe his mother first, then himself when he writes the following about her:

His mother silent beside him

her yellow hair trapped and placid in a hairnet

her clean cream jodhpurs red collar black riding jacket

her stock like a bandage

her gold pin

adorned with the mask of a fox.

(Essex 6) 
Out of his nostalgia for his deceased mother, Motion remembers every detail describing his mother's clothes clearly, as if the event happened the day before. Her image is still engraved in his mind and pops every now and then. The use of the poetic devices, such as: assonance (e.g. his, him / silent, beside), alliteration (e.g. her, hair, hairnet / clean, cream, collar), consonance (e.g. and, trapped, placid / stock, like), and anaphora (her); as well as the hissing sound (s) (e.g. silent, beside, placid, stock, mask) gives a musical effect which accompanies Motion's feelings when he describes his mother. The spaces between the words or the phrases in the lines, which can be noted along the whole volume, work like caesuras. They attract the attention of the reader to what is before and what is after them and give some sort of relief from reading, especially with the frequently used run-on-line technique. Motion also uses simile cleverly in the poem. In the fourth line of the above stanza, the simile (her stock like a bandage) clarifies her selfconfidence. Besides, it also hints at her accident and her harm as an aftermath of riding and hunting. The phrase (the mask of a fox) implies the cause of his mother's death, as she had her riding accident while she was chasing a fox.

Motion also uses implications when he declares in the stanza following the above quoted one that (He does not approve) hunting to which he refers as (this subject) without mentioning it directly; as it is the main cause of losing his mother and consequently led to his grief and psychological trauma. His self-confrontation at this point concerning hunting is not complete. At that time he was "seventeen confident opinionated / and definitely at odds / on this subject at least" (6), yet he can't oppose his mother. A year before his mother's accident, when he was sixteen and at Radley School, Motion said to his younger brother Kit: "I'm going to change a few things ... Such as hunting, I'm not going to do that anymore. Or shooting" (Blood 274). But he can't object to his mother's decision to do it herself: "he is silent. / he cannot bring himself / to have that argument again" (Essex 6). But, he hates hunting and wishes, now, that he could have prevented her: "he has expected this all his life / feared would be better / he has feared this all his life" (21). His fears have come true. She has died because of hunting, and now he is longing for her presence so much.

Longing for the presence of his mother, Motion expresses that he has kept looking at his mother when he has ridden the bus, after she has dropped him at his friend's house: "He flinches away / to discover his mother's face is / already no longer her face / but an after-image" (Essex 8). When the bus begins to move: "he lurches for a last glimpse of the lane back to the / village / and finds no car in 
sight"(9). Even when he is with Juliet, he cannot forget his mother. Her image and her voice are haunting him. He painfully recalled these memories:

He spares a thought for his own mother.

Will she be home already

defeated

she would say that

defeated

by cold.

Her voice stays with him through the back yard

ghosting

boiler shed

ghosting

dog kennel

ghosting

wood shed

ghosting.

But he cannot hear what the ghost says.

(Essex 12-13)

The lines of the above stanza are very short; some lines consist of one or two words only. Thus, they are suitable for the poet's thoughts about his mother which were like flashes that sparkle in his mind. He tries to guess her condition in that bad weather or what she has been doing in her hunting journey. He endeavors to soothe his torment, to escape from her haunting image and voice, and to find a way out of his sometimes unjustifiable fear, but in vain. Hence, these lines increase the reader's suspense. Run-on-line technique helps the poet to recall his flow of the ideas at that time and to express his inner feelings. The first and the last lines are only end-stopped lines; they are complete thoughts in themselves. The first line shows how he is so attached to his mother and prepares the reader to accept the poet's feelings expressed in the following lines. He wants to come back quickly in 
order to tell his mother how he has spent the time without her. He used to speak with her as close friends especially on his school holidays, as he attended boarding schools: "By the end of the holidays, mum and I were stuck together more tightly than ever" (Blood 299). When he became ill at Radley and was compelled to come back and stay at home, both he and his mother became more and more attached, he comments writing that:

The thing I liked best about being ill wasn't reading, it was talking to mum, the daytimes in between her chores, when she sat in the red chair under the window, with the chestnut taking deep breaths behind her, and we turned things over like people playing with stones in a stream. Or the evenings when we were waiting for dad's car, and the clock slowed down, and the light in my room changed to dim green thanks to the tree.

$($ Blood 294 - 5)

The above quotation from Motion's In The Blood clarifies the strong ties between him and his mother. They used to talk together like friends and stay day and night together. On reading these words, the readers would sympathize with him and understand the painful effect of recalling these memories. To complete the process of self-confrontation to mitigate his nostalgia, the poet remembers the sad memories of the day of his mother's accident in a narrative form or a kind of dramatic poetry. This story telling method attracts the reader's attention adding more and more details in a building up way. Additionally, "using the narrative approach" is a "fruitful" technique in the "therapeutic writing" (White et al 15). It allows "the individuals to externalize their issues rather than internalize them" (Ackerman 2). Motion is skillful in using the narrative technique in poetry. Using this technique helped him in his self-exposition and self-confrontation, and consequently in his self-healing process. As if he were writing a dramatic work, Motion uses different kinds of characters. The main characters of this first part are: the poet, his mother, his father, Juliet, and her mother. The minor characters are: his grandmother, Mrs. Hill, a priest, and the people in the party.

As a climax of his narration or his nostalgic story about his mother, he maintains that Juliet's mother told him about his mother's accident all of a sudden. As a reaction, he listened silently and was "dry-eyed", but his "brain" was "juddering" and full of "Turbulence" (Essex 20). The poet then keeps repeating the word "injury" several times afterwards; as if he wants to convince and accommodate himself to his mother's new condition. He attended the party to overcome his worries (22) but he was "distracted" (25), and no one cared. His 
nostalgia and longing for his mother push him to blame himself so much; how could he attend a party while his mother was dying, even though it was his father's order? He writes in a sad tone: "His mother is dying probably / even as he stands here. / His mother is dying." (24).

Notably, along the poem, the poet uses the present simple, present perfect and / or the present continuous tenses in order to give continuity and reproduction to the experience, due to its great and lasting effect on him. Thus, the reader lives the events as they have happened. By doing this, he confronts himself in order to get rid of the tormenting nostalgic feelings and to have a psychological relief.

Yet, he is still obsessed with his mother and feels nostalgic for her, and even is suffering from the negative effects of his nostalgia: "suddenly everything irritates him. / Everything" (Essex 38). He still yearns for her. He has strived so much to forget her; but in vain. At the time of the accident, for example, when he was in the party with Juliet, away from all people, he thought of his mother and all her belongings. He could recall and enumerate them one by one over and over again (Essex 28). Now, his nostalgic feelings have escalated. Additionally, he suffers from insomnia and sadness: "The moon peers at him / over her neat cloud fold / and decides it is time to change her orbit. / She swings closer to the Earth." (Essex 31). He thinks that something abnormal has happened, so it is accompanied by disorder in nature; the moon will change its orbit and come closer to Earth. In his solitude, no one cares about his suffering or shares his burden. He complains to the moon; it is the only one who sympathizes with him. He explains these moments writing the following:

The moon in sympathy

Rests her entire weight

On the shell of his chest.

He embraces her and

She absorbs him.

He feels nothing at all.

(Essex 32)

To complete his self-confrontation and the process of healing from nostalgia, the poet bravely faces his depression and agony. He attempts to face his sadness: "He finds himself afloat / in a new gravity / thinking about thinking / about living 
in sadness" (Essex 42). However, he confesses that his mother's accident, her coma and her slow death for nine years and then her death caused him deep feelings of grief: "Grief / ... / Sorrow the same. / Rage the same. / Limbo then limbo / and better accept it. / Limbo" (46 - 47).

Psychologists state that grief has five stages. These stages "are tools to help us frame and identify what we may be feeling" (Kubler-Ross and Kessler 7). All of these five stages of grief (or some of them) that some people undergo help them to adapt themselves to the loss and to accept it. Remarkably, undergoing these stages is a step towards healing. These stages are: "denial, anger, bargaining, depression, and acceptance" (Axelrod 1). In the following quotation from Essex Clay, Motion shows that he has undergone some of the stages of grief (anger and depression) till he reached the stage of accepting his loss in spite of his sadness and agony. His loss is metaphorically represented as "Limbo". In therapeutic poetry, the metaphor "is not merely a poetic device". But it is "an essential aspect" of the poet's "mental and physical furniture, prior to thought; it is the 'open sesame' to memories. It is the way of linking up the desperate elements" of himself and his world; "a way of enabling the voices of these elements - normally clamoring silently - to speak and be heard" (Bolton, "Every Poem" 117). Here, the repeated metaphor of a "Limbo" shows his perplexing state. He is caught in a horrible situation; and it is unclear what will happen next in his life. Yet, he should convince himself to accept it. He wrote:

In this way

Grief becomes

The strange contentment

Of living in suffering

Without the possibility

Of such unhappiness

In whatever else

Remains of life.

Grief

Grief whispering 
he will be content

to live in a mirror-bright shining steel universe

that can never be altered.

(Essex 47)

The poet has tried to cope with his loss. He has convinced himself that "he will be content" with his destiny. Consequently, he has accepted his loss. Reaching the stage of acceptance is:

A gift not afforded to everyone. Acceptance or coping with loss is ultimately a deeply personal and singular experience - nobody can help you go through it more easily or understand all the emotions that you're going through. At this stage, the person acknowledges entirely the loss and completes his life.

(Axelrod 1)

It is apparent that Motion has helped himself to reach this stage of acceptance. He has made his self-confrontation bravely through writing poetry. Now, he can overcome the negative effects of his nostalgia for his mother and for his homeland. He can cope with the "universe / that can never be altered". His poetry has achieved its therapeutic aim: "He thinks for the time being / there is nothing more he can say" (Essex 62).

The tormenting feelings of nostalgia for Motion's late mother can be felt also for his late father though in a lesser degree. He gathers them in the last scene of the first part of the volume and the first scene of the second one. Besides, the dedication of this volume is for both of them: "Gillian Motion 1928 - 1978 and Richard Motion 1921 - 2006". Although he has loved his mother far more than his father, he felt nostalgic for him also. He writes about his relation to his father saying: "I didn't want to admit it, but there was always a wrinkle when dad came home" (Blood 295). Motion's mother was always trying to soothe his fear of his father saying: "your father was brought up very strictly" (Blood 297). But, Motion innately loves his father, and feels nostalgic for him.

This nostalgia for his late father is the subject of the second part of his volume, Essex Clay. He begins it with his father's depression and retirement from social life after his mother's death and then his fatal disease and his death. He opens the second part as follows: 
Since they buried his mother

his father has moved two hundred yards

and gone to ground himself

in the humid labyrinth fox-earth of a farm cottage

defended by beech hedge fortifications.

He has retired from human friendships

and grown close

to television.

(Essex 67)

In the second part of his poem Essex Clay, Motion uses again the narrative technique as he did in the first part. In the above opening stanza, he relates this part to the preceding one. He begins it where he has ended the first. The first line begins with a third plural pronoun "they" as used in the first part. But here it means "he" and "his father". The burial of his mother seems to be the main tormenting event in his life which has caused his sadness and suffering. Hence, he ends the first part with it and begins the second part with it. The phrase "two hundred yards" is a hyperbole; which expresses his father's complete isolation far away from all people. The white space before it, which works as a medial caesura, adds to the meaning and strengthens this hyperbole attracting the attention of the reader to what is following. The phrase "to ground himself" in the third line shows how his father's life seemed to have come to an end voluntarily when his mother died, he has entombed himself in that far away cottage. He has deserted the life of the city and also his friends. His only way of amusement is TV. He is waiting for his death: "bowed his head / with the same bafflement at her grave / as the empty grass gap waiting beside it" (67).

In contrast to the technique of the chronological order of the narration used in the first part, Motion deals with the story of his father's death in a flashback technique. He begins the story with his father's death then tells the readers how it has happened. In the exposition of his narration, the poet shows that after the mother's death, his father retired from social life and kept visiting her grave for twenty eight years till his death: "and now his patience has been rewarded" (67). Motion considered that his father's death was 'a reward' for his patience for all these years 
in order to be with his mother. Then, Motion starts to tell the story of his father's death.

The story of the death of Motion's father begins when he one day of January tells Motion that he had "bone cancer" (68). Ominous symbols appear before this horrible news. January is a month of winter. Its coldness is a symbol of annihilation and death. The "black lime tree branches spotted with white fungus / latticing his window" foreshadow a catastrophe. Lime tree has "a special place in symbolism" (Varan 237). It has many connotations and related meanings in several cultures. In literature, it may be "a symbol of fragility" (Beidermann 208), or "protection, immortality, good luck, love, sleep" (Fărcaş 192). It may also be, in a more general sense, "a symbol of life and death" (Varan 237). Here, Motion describes the branches of the lime tree as "black" confining its symbolic references to mortality and death. The poet hints at his father who is related to most of these symbolic references of the tree, but his life then comes to an end. He is attacked by malicious cancer cells, which are symbolized as "spotted with white fungus" (68).

Facing the reality of his father's fatal illness, Motion records his painful feelings honestly: "he wonders under his breath / could it be ending now / this eternal interval with his father / this lifetime of silence" (70). He wonders whether the life of his father who was always strong, wise and silent ends now. He feels "Throttled ... Choked". He recalls his feelings at that time when he wrote:

At the very idea

a sensation like sea water

seeping through dry sand

consumes him.

Motion was absorbed and consumed completely in his surprise and sadness, because of the news of his father's fatal illness. The simile of the second line: "a sensation like sea water" expresses the explicit comparison enriching the intended meaning. For the first time in his life, Motion feels like a son towards his father: "he feels himself a son / as never before" (79). He started to fear the end of his father's life. For the first time, he realizes that he will lose protection, safety and kindness of his father. However, he starts to feel responsible for his father. $\mathrm{He}$ accompanies his father to the hospital and takes care of him. The rising action of 
this dramatic poem tackles this last period of his father's life and the horrible consequences of his fatal illness. So the setting changes to the hospital room of his father. The detailed sorrowful narration increases the dramatic intensity of the story.

On expecting the end of his father's life, Motion began to see his mother as waiting for his father in Heaven: "craning himself up to the moon of his own face / and his mother / a smear of bridal white" (80). Motion "examines" the face of his unconscious father and "discovers it more and more nearly / resembles his own face" (83). Surprisingly, he "discovers" for the first time that they resemble each other. For the first time, he looks attentively and closely at his father's face and becomes aware of their resemblance. Recalling his father's countenance increases the attachment between them. It also would impart to him self-confidence and turn the negative feelings of his nostalgia into positive. Mentioning these details expresses the poet's suffering on remembering them. The climax of the story of his father comes "with no warning"; his father dies. The poet repeats the phrase: "His invincible father" (84). The falling action of the narration of his father's story displays his father's funeral. The setting changes to the churchyard.

As a way of mitigating his nostalgia and his painful feelings at the loss of both his father and his mother, Motion convinces himself that they will be happy in their afterlife because of their union again, he writes:

His mother who has waited thirty years

for her husband to climb into bed beside her

and whose name has faced into the rain so long

its letters are now slivers of grey moss

his mother

blackmails everyone.

The poem achieves its therapeutic effect at its end. It shows how the poet has completed his self-confrontation and healing process. The negative effects of his nostalgia for his parents have been turned into positive ones, although his nostalgia has never been eliminated. The second part of the poem ends as follows:

None of which

he thinks 
as he stumps up the incline of the village street

towards the wake in the garden of his father's cottage

makes the slightest sense

and will never.

These lines tackle his nostalgia for his parents and the events of their death. After coming back from his father's funeral, Motion returns to his father's cottage in which his father stayed after his mother's death in a complete isolation and in which Motion began the narration of the second part of his poem. This cottage is the last shelter for the poet. It is the place in which he can ruminate on his memories. There is no use of punctuation, especially the use of commas. Grammatically, there should be a comma after "which" in the first line and another one after "cottage" in the fourth line. The poet didn't want to stop the flow of his ideas by using punctuation marks, to encapsulate his thoughts or to separate the sentences dealing with his parents from his own sentences. Yet, as a poetic license, the disregard of using the punctuation marks can be compensated by the richness of the intended meaning.

The intended meaning in this last stanza of the second part of the poem reveals the state that the poet has achieved of complete acceptance and consent. $\mathrm{He}$ bravely accepts his parents' death and confronts the loss: "None of which / ... /makes the slightest sense / and will never". The sentence: "he stumps up the incline of the village street" contains some symbols. The "village street" stands for life in general; in which he now "stumps up". Yet, he cannot find a shelter except in his father's cottage which is full of his memories. These memories contain his roots. Recalling them can transport him to a new hope to go on with his life. However, he cannot separate himself from them. Consequently, he cannot separate himself from his nostalgic feelings, but he succeeded in facing its negative effects and tormenting feelings. He has written these poems in order to mitigate his nostalgia's painful effects. He bravely has confronted himself and confessed his tormenting feelings and accepted his losses. Through this healing process, these poems have alleviated his heartbreaking feelings and created new hope in life. Thus, Motion's Essex Clay has become 'therapeutic' for him. He has achieved his therapeutic aim. It is scientifically proved that: "Poems profoundly alter the man or woman who wrote them. Because poetry can only be written from the otherwise most difficult to reach parts of oneself and one's world, in a process similar to the most effective therapy or analysis, or to the therapeutic use of the other arts." (Flint vi) 


\section{Works Cited}

Ackerman, Courtney. "19 Narrative Therapy Techniques, Interventions + Worksheets [PDF]". Positivepsychology.com, 18 June 2017, https://positivepsychology.com/narrative-therapy/

Axelrod, Julie. "The 5 Stages of Grief and Loss". PsychCentral, 1995, psychcentral.com/lib/the-5-stages-of-loss-and-grief

Beidermann, Hans. Dictionary of Symbolism: Cultural Icons and the Meanings Behind Them. Translated by James Hulbert, New York: Facts On File Inc., 1992.

Bolton, Gillie. The Therapeutic Potential of Creative Writing: Writing Myself. London: Jessica Kingsley, 1999.

---. "Introduction". Writing Cures: An Introductory Handbook of Writing in Counselling and Therapy, edited by Gillie Bolton, Stephanie Howlett, Colin Lago and Jeannie K. Wright, Chapter 10, Hove and New York: BrunnerRoutledge, 2004, pp.1 - 4.

--- and John Latham. "Every Poem Breaks a Silence That Had To Be Overcome: The Therapeutic Role of Poetry Writing". Writing Cures: An Introductory Handbook of Writing in Counselling and Therapy, edited by Gillie Bolton, Stephanie Howlett, Colin Lago and Jeannie K. Wright, Chapter 10, Hove and New York: Brunner-Routledge, 2004, pp.106 - 122.

Esterling, B.A., L'abate, L., Murray, E.J. \& Pennebaker, J.W. "Empirical Foundations for Writing in Prevention and Psychotherapy: Mental and Physical Health Outcomes". Clinical Psychology Review, vol. 19, no. 1, 1999, pp.79-96.

Fărcaş, Camelia Paula; Sorina Farcas; Vasile Cristea; Tudor Ursu. "The

Symbolism of Garden and Orchard Plants and Their Representation in Paintings". Research Gate, January 2015, pp.189-200.

Flint, Rose. "Fragile Space: Therapeutic Relationship and The Word". Writing in Education, vol. 26, 2002, pp. ii-viii.

Kubler-Ross, Elisabeth and David Kessler. On Grief and Grieving: Finding the Meaning of Grief through the Five Stages of Loss. New York: Simon and Schuster, 2005.

Matt, Susan J. Homesickness: An American History. Oxford University Press, 2011. 
Matthews, Sophie. "Are Feelings of Nostalgia Really Just a Symptom of Depression?” 13 August 2018, https://www.quora.com/Are-feelings-ofnostalgia-really-just-a-symptom-of-depression

Motion, Andrew. "About to fly back from Baltimore to London, for a week of seeing my children and friends. And reading at Ledbury in Saturday. Right now, though, big thunderstorm over Chesapeake." Twitter, 3 July 2019, 02:21 pm. Twitter.com@motionandrew.

---."Andrew Motion on Stisted: 'That's where I first began to care about poems"”. The Guardian, Sat 21 Jul 2018, theguardian.com/books/2018/jul/21/made-instisted-andrew-motion

---. Essex Clay. London: Faber \& Faber Ltd., 2018.

---. "Hotlines to the Nation's Heart". The Guardian, Saturday 11 March 2000 https://www.theguardian.com/books/2000/mar/11/andrewmotion.poetry

---. In the Blood: A Memoir of My Childhood. London: Faber \& Faber Ltd., 2006.

---. Selected Poems1976 - 1997. London: Faber \& Faber Ltd., 2010.

"Nostalgia". https://en.wikipedia.org/wiki/Nostalgia\#As_a_comfort

Pearsall, Leslie. "Homeage to the New Laureate". Hiroshima Jogakuin University English / American Literature Studies, vol. 8, no. 83, 1999, pp. 105 - 131.

Sexton, Timothy. "The Poems of Andrew Motion: Analysis". GradeSaver, 2019, https://www.gradesaver.com/the-poems-of-andrew-motion/study-guide/analysis

Tierney, John. "Science of Nostalgia". an interview on The New York Times: Timesvideo, By Jeffery DelViscio, Pedro Rafael Rosado, Kriston Lewis, Robin Lindsay, Abe Sater and David Corcoran, 9 July 2013, 4:34 https://www.nytimes.com/video/science/100000002325921/science-ofnostalgia-html 
---. "What Is Nostalgia Good For? Quite a Bit, Research Shows". The New York Times: Science, 8 July 2013.

Varan, Alina-Maria; Claudia Borlea; Fl. Madoşa; E. Szekely. "The Symbolism of the Linden Tree". Journal of Horticulture, Forestry and Biotechnology, Banat's University of Agricultural Sciences and Veterinary Medicine Timişoara Faculty of Horticulture and Sylviculture, vol. 19, no. 2, 2015, pp.237- 242.

White, Michael; Michael Kingsley White; Made Wijaya; David Epston. Narrative Means to Therapeutic Ends. New York: W.W. Norton, 1990.

Wilson, P., J. Exshaw, J. Esdall, R. James, S. Price, and M. Williamson. The Minor Poets, Or, the Works of the Most Celebrated Authors, of Whose Writings There are But Small Remains, Viz. the Earl of Roscommon, the Earl of Dorset, the Earl of Hallifax, Sir Samuel Garth, George Stepney, ... William Walsh, ... Thomas Tickell, ... Thomas Sprat, ... In Two Volumes. Volume 2, Dublin: MDCCLI, 1751.

Woolf, Virginia. Moments of Being. Edited by Jeanne Schulkind, Harcourt Brace Jovanovich, 1985.

Wright, Jeannie. "Online Counseling Learning from Writing Therapy". British Journal of Guidance \& Counseling, vol. 30, no. 3, 2002, p.1s-14. 